\title{
Lack of Deoxyribonucleic Acid Relatedness Between Haemophilus ducreyi and Other Haemophilus Species
}

\author{
ISABELLE CASIN, ${ }^{1 *}$ FRANCINE GRIMONT, ${ }^{2}$ PATRICK A. D. GRIMONT,${ }^{2}$ AND \\ MARIE-JOSE SANSON-LE PORS ${ }^{1}$
}

Service de Bactériologie-Virologie, Université Paris VII, Hôpital Saint-Louis, F-75010 Paris, France, ${ }^{1}$ and Unité des Entérobactéries, Institut National de la Santé et de la Recherche Médicale Unité 199, Institut Pasteur, F-75724 Paris Cedex 15, France ${ }^{2}$

\begin{abstract}
Deoxyribonucleic acid relatedness studies (S1 nuclease method) showed that 25 strains of Haemophilus ducreyi from diverse geographic origins form a homogeneous deoxyribonucleic acid hybridization group. A total of 17 type or reference strains of established or proposed Haemophilus species were 0 to $6 \%$ related to $H$. ducreyi at the optimal temperature. These findings do not support the assignment of $H$. ducreyi to the genus Haemophilus.
\end{abstract}

The classification of the causative agent of chancroid, Haemophilus ducreyi (Neveu-Lemaire 1921) Bergey, Harrison, Breed, Hammer and Huntoon $1923(1,13)$, in the genus Haemophilus is based mainly on the demonstration of a requirement for hemin, a nitrate reductase activity, and a guanine-plus-cytosine content of the deoxyribonucleic acid (DNA) (38 mol\%) similar to that of Haemophilus influenzae (11). However, $H$. ducreyi, a saliently unreactive bacterium in conventional biochemical tests, is phenotypically different from all other Haemophilus species (11).

The purpose of the present study was to determine the extent of genetic variation among chancroid isolates of $H$. ducrey $i$ and the levels of relatedness between $H$. ducreyi and other Haemophilus species.

\section{MATERIALS AND METHODS}

Bacterial strains. The origins of the $25 \mathrm{H}$. ducreyi strains studied are listed in Table 1. The type or reference strains of the other Haemophilus species studied are listed in Table 2.

The $H$. ducreyi isolates from Hôpital Saint-Louis, Paris, France, were identified as described elsewhere (5). Stock cultures of $H$. ducreyi were maintained at $-70^{\circ} \mathrm{C}$ in PPLO broth (Difco Laboratories, Detroit, Mich.) supplemented with $40 \%$ (vol/vol) Eagle minimal essential medium (Institut Pasteur Production, Marnes-la-Coquette, France), 20\% ( $\mathrm{vol} / \mathrm{vol}$ ) fetal bovine serum (Industrie Biologique Française, Villeneuve-la-garenne, France), and $15 \%$ (vol/vol) glycerol. Working cultures were maintained under $5 \% \mathrm{CO}_{2}$ at $36^{\circ} \mathrm{C}$ by inoculation every 3 days onto PPLO agar containing $40 \%$ $(\mathrm{vol} / \mathrm{vol})$ Eagle minimal essential medium and $20 \%(\mathrm{vol} / \mathrm{vol})$ fetal bovine serum.

DNA preparation. After 2 to 3 days of incubation at $37^{\circ} \mathrm{C}$ in $5 \% \mathrm{CO}_{2}$, the growth from 10 plastic flasks (Nunclon delta SI; $800 \mathrm{ml}$; Nunc. Copenhagen, Denmark) containing $75 \mathrm{ml}$ of PPLO agar containing $40 \%$ ( $\mathrm{vol} / \mathrm{vol})$ Eagle minimal essential medium and $20 \%$ (vol/vol) fetal bovine serum was harvested in $200 \mathrm{ml}$ of a solution containing $0.05 \mathrm{M}$ tris(hydroxymethyl)aminomethane, $0.05 \mathrm{M}$ ethylenediaminetetraacetate, and $0.1 \mathrm{M} \mathrm{NaCl}(\mathrm{pH} 8.0)$. Then, $4 \mathrm{ml}$ of a $25 \%(\mathrm{wt} / \mathrm{vol})$ aqueous solution of sodium dodecyl sulfate (Sigma Chemical Co., St. Louis, Mo.) and $0.6 \mathrm{ml}$ of a $2 \%$ (wt/vol) pronase (Calbiochem-Behring, La Jolla, Calif.) solution were added. The mixture was vigorously shaken and incubated at $37^{\circ} \mathrm{C}$ overnight to achieve cell lysis.

\footnotetext{
* Corresponding author.
}

DNA was extracted and purified from the cell lysate by using previously described procedures (4). Some of the DNA preparation was sheared by sonication (4). Sheared DNAs were dialyzed overnight against $0.042 \mathrm{M} \mathrm{NaCl}$ and stored at $4^{\circ} \mathrm{C}$ over a layer of chloroform.

DNA-DNA hybridization. Native DNA was labeled in vitro by nick translation (10). The S1 nuclease method (8) used (S1 nuclease-trichloroacetic acid procedure) has been described elsewhere (10), except that all volumes were reduced by one-half.

The temperature $\left(T_{m}\right)$ at which $50 \%$ of the reassociated DNA became hydrolyzable by the $S 1$ enzyme was determined (8). The difference $\left(\Delta T_{m}\right)$ between the $T_{m}$ of a homologous reaction and the $T_{m}$ of a heterologous reaction is an estimate of divergence between two DNAs (3).

Guanine-plus-cytosine content. The melting temperatures of $50-\mu \mathrm{g} / \mathrm{ml}$ DNA solutions in $0.1 \times \mathrm{SSC}$ buffer $(1 \times \mathrm{SSC}$ is $0.15 \mathrm{M} \mathrm{NaCl}$ plus $0.015 \mathrm{M}$ trisodium citrate) were measured with a Gilford spectrophotometer. The guanine-plus-cytosine contents of DNAs were determined twice from melting temperatures by the equation of Owen et al. (14). Escherichia coli $\mathrm{K}-12$ DNA taken to have a guanine-plus-cytosine content of $50.6 \mathrm{~mol} \%$ was included as a standard.

\section{RESULTS}

Guanine-plus-cytosine content. The guanine-plus cytosine content of the DNA of $H$. ducreyi type strain CIP 542 was 39 mol\%.

DNA relatedness. The DNA relatedness results obtained with labeled reference DNA from strain CIP $542^{\mathrm{T}}$ ( $\mathrm{T}=$ type strain) and unlabeled DNAs from 24 strains of $H$. ducrey $i$ are shown in Table 1. The S1 nuclease-resistant core (in the incubated control tubes containing only denatured labeled DNA) was calculated to be $3 \pm 1 \%$ (mean \pm standard deviation). At $60^{\circ} \mathrm{C}$, the $24 \mathrm{H}$. ducreyi strains were $94 \pm 6 \%$ related to strain CIP $542^{\mathrm{T}}$. The $\Delta T_{m}$ values between $H$. ducreyi strains and strain CIP $542^{\mathrm{T}}$ were less than $1{ }^{\circ} \mathrm{C}$.

The DNA relatedness results obtained with the same labeled DNA from strain CIP $542^{\mathrm{T}}$ and DNAs from 17 other representative strains of the genus Haemophilus are shown in Table 2. All Haemophilus species studied (other than $H$. ducreyi) were 0 to $6 \%$ related to $H$. ducreyi CIP $542^{\mathrm{T}}$. 


\section{DISCUSSION}

The guanine-plus-cytosine content of the DNA of $H$. ducreyi found in this work $(39 \mathrm{~mol} \%)$ is within $1 \mathrm{~mol} \%$ of the value $(38 \mathrm{~mol} \%)$ published by Kilian (11).

The DNA relatedness results provide evidence that strains identified as $H$. ducreyi constitute a homogeneous genomic species. Since the level of DNA hybridization between $H$. ducreyi and the other Haemophilus species was very low, our results provide no support for assignment of $H$. ducreyi to the genus Haemophilus.

Most species in the family Pasteurellaceae (i.e., members of the genera Pasteurella, Haemophilus, and Actinobacillus) were at least $30 \%$ related when the spectrophotometric method was used to assess DNA relatedness (16). However, DNA reassociation values determined with the hydroxyapatite method $(6,18)$, the nitrocellulose filter method $(6,7)$, or the S1 nuclease method (9) showed the Pasteurellaceae to be genomically heterogeneous, with some groups showing little or no DNA relatedness (0 to $10 \%$ similarity). No $H$. ducreyi strain had been included in published DNA relatedness studies prior to the present work.

The etiological agent of chancroid was first isolated on a medium supplemented with $30 \%$ (vol/vol) fresh rabbit blood (2), and this apparent requirement for blood led to the inclusion of "Coccobacillus ducreyi" (13) in the genus Haemophilus (1). Lwoff and Pirowsky (12) showed that $H$. ducreyi requires $\mathrm{X}$ factor (protoporphyrin IX or protoheme). A key characteristic of the genus Haemophilus is the requirement for $\mathrm{X}$ factor or $\mathrm{V}$ factor (nicotinamide adenine dinucleotide or nicotinamide adenine dinucleotide phosphate) or

TABLE 1. Reassociation of DNA from $H$. ducreyi CIP $542^{\mathrm{T}}$ with DNAs from other $H$. ducreyi strains

\begin{tabular}{|c|c|c|}
\hline \multicolumn{2}{|c|}{ Source of unlabeled DNA } & \multirow{2}{*}{$\begin{array}{c}\% \text { Relative } \\
\text { binding at } \\
60^{\circ} \mathrm{C}\end{array}$} \\
\hline Strain ${ }^{a}$ & Geographic origin & \\
\hline CIP $542^{\mathrm{T}}$ & Vietnam (Hanoi) & $100(0.0)^{b}$ \\
\hline HSL 82013 & Portugal (Lisbon) & 95 \\
\hline HSL 83002 & France (Paris) & 85 \\
\hline HSL 82010 & Senegal & 97 \\
\hline HSL 79001 & France (Paris) & 100 \\
\hline HSL 83004 & India & 93 \\
\hline HSL 76005 & Singapore & $92(0.4)$ \\
\hline HSL 82006 & Singapore & 82 \\
\hline HSL 80002 & India & $98(0.7)$ \\
\hline HSL 82009 & Portugal (Porto) & 94 \\
\hline HSL 83013 & France (Paris) & 88 \\
\hline HSL 82011 & Antilles & $80(0.1)$ \\
\hline HSL 83003 & France (Paris) & 96 \\
\hline HSL 82014 & France (Paris) & $90(0.3)$ \\
\hline HSL 83014 & France (Paris) & 99 \\
\hline CCUG 7309 & Canada (Winnipeg) & 99 \\
\hline CCUG 7310 & Canada (Winnipeg) & $93(0.2)$ \\
\hline CCUG 7312 & Canada (Winnipeg) & 98 \\
\hline CCUG 7781 & Denmark (Copenhagen) & 100 \\
\hline CCUG 8157 & Thailand & 95 \\
\hline CCUG 8224 & Spain (Mallorca) & 98 \\
\hline CCUG 8759 & Portugal & 96 \\
\hline CCUG 9276 & East Africa & 94 \\
\hline CCUG 10058 & Sweden (Karlstad) or Spain & 93 \\
\hline Slootmans 3141 & Kenya & 95 \\
\hline
\end{tabular}

${ }^{a}$ CIP, Collection de l'Institut Pasteur, Paris, France; HSL, Laboratoire Central de Microbiologie, Hôpital Saint-Louis, Paris, France; CCUG, Culture Collection, University of Götebort, Göteborg, Sweden (E. Falsen); Slootmans, H. Slootmans, Institut voor Tropishe Geneeskunde Prins Leopold, Antwerp, Belgium.

${ }^{b}$ The values in parentheses are $\Delta T_{m}$ values (in degrees Celsius).
TABLE 2. Reassociation of DNA from $H$. ducreyi CIP $542^{\mathrm{T}}$ with DNAs from other Haemophilus species

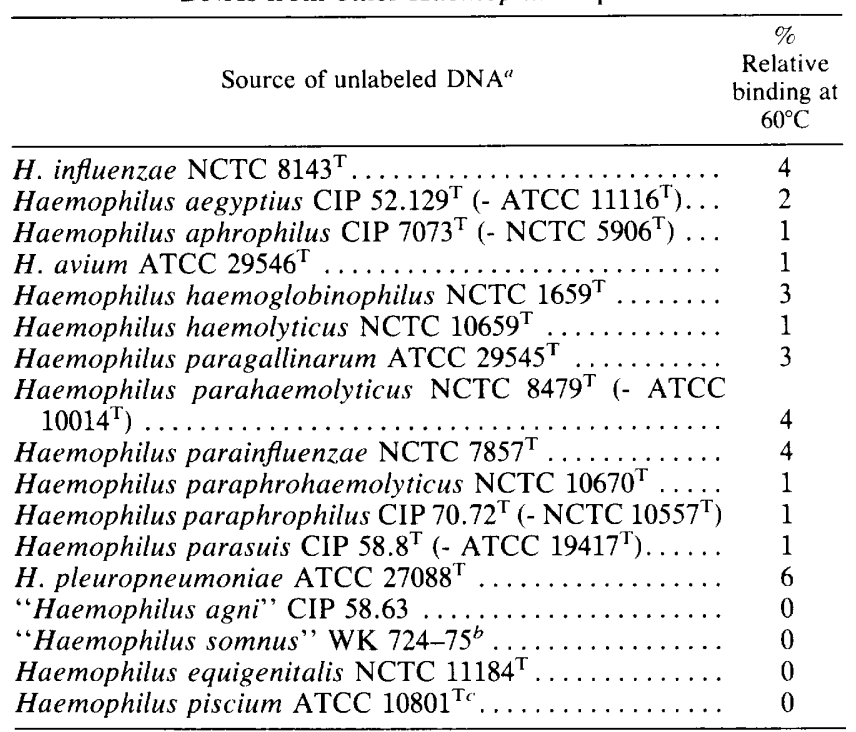

"ATCC, American Type Culture Collection, Rockville, Md.; CIP, Collection de l'Institut Pasteur, Paris, France; NCTC, National Collection of Type Cultures, London, England.

${ }^{b}$ Received from Institut Mérieux, Lyon, France.

${ }^{c}$ Now considered an atypical strain of Aeromonas salmonicida (15).

both. However, this key characteristic for circumscribing the genus Haemophilus has been challenged by DNA homology studies. Pohl et al. (17) have shown that Haemophilus pleuropneumoniae is genetically closer to Actinobacillus ligneresii than to $H$. influenzae and that V-factor-requiring and V-factor-nonrequiring strains could constitute a single genomic species. Accordingly, $H$. pleuropneumoniae was transferred to the genus Actinobacillus (17). Similarly, Haemophilus avium belongs to the same genomic group as Pasteurella gallinarum irrespective of different growth factor requirements (17).

The family Pasteurellaceae is undergoing complete revision. At this time, we refrain from proposing nomenclatural changes until DNA relatedness studies of the genus Haemophilus and the family Pasteurellaceae provide more comprehensive results.

\section{ACKNOWLEDGMENTS}

One of us (I.C.) thanks L. Le Minor for hospitality in the Unité des Entérobactéries and Y. Pérol for advice and encouragement during this work.

\section{LITERATURE CITED}

1. Bergey, D. H., F. C. Harrison, R. S. Hammer, and F. M. Huntoon. 1923. Bergey's manual of determinative bacteriology, 1st ed. The Williams \& Wilkins Co., Baltimore.

2. Besançon, F., V. Griffon, and L. Le Sourd. 1900. Recherches sur la culture du bacille de Ducrey. Ann. Dermatol. Syphiligr. 11:1-20.

3. Brenner, D. J. 1978. Characterization and clinical identification of Enterobacteriaceae by DNA hybridization. Prog. Clin. Pathol. 7:71-117.

4. Brenner, D. J., A. C. McWhorter, J. K. Leete Knutson, and A. G. Steigerwalt. 1982. Escherichia vulneris: a new species of Enterobacteriaceae associated with human wounds. J. Clin. Microbiol. 15:1133-1140.

5. Casin, I. M., M. J. Sanson-Le Pors, M. F. Gorce, M. Ortenberg, and Y. Perol. 1982. The enzymatic profile of Haemophilus ducreyi. Ann. Microbiol. (Paris) 133B:379-388. 
6. Christiansen, C., E. Hansen, and A. Friis-Møller. 1981. Homology between DNA from selected strains of the genera Pasteurella, Actinobacillus, and Haemophilus, p. 158-160. In M. Kilian, W. Frederiksen, and E. L. Biberstein (ed.), Haemophilus, Pasteurella, and Actinobacillus. Academic Press, Inc., London.

7. Coykendall, A. L., J. Setterfield, and J. Slots. 1983. Deoxyribonucleic acid relatedness among Actinobacillus actinomycetemcomitans, Haemophilus aphrophilus, and other Actinobacillus species. Int.J. Syst. Bacteriol. 33:422-424.

8. Crosa, J. H., D. J. Brenner, and S. Falkow. 1973. Use of a single-strand-specific nuclease for analysis of bacterial and plasmid deoxyribonucleic acid homo- and heteroduplexes. J. Bacteriol. 115:904-911.

9. Escande, F., F. Grimont, P. A. D. Grimont, and H. Bercovier. 1984. Deoxyribonucleic acid relatedness among strains of Actinobacillus spp. and Pasteurella ureae. Int. J. Syst. Bacteriol. 34:309-315.

10. Grimont, P. A. D., M. Y. Popofi, F. Grimont, C. Coynault, and M. Lemelin. 1980. Reproducibility and correlation study of three deoxyribonucleic acid hybridization procedures. Curr. Microbiol. 4:325-330.

11. Kilian, M. 1976. A taxonomic study of the genus Haemophilus, with the proposal of a new species. J. Gen. Microbiol. 93:9-62.

12. Lwoff, A., and Y. Pirowsky. 1937. Determination du facteur de croissance pour Haemophilus ducreyi. C. R. Séances Soc. Biol.
Paris 124:1169-1171.

13. Neveu-Lemaire, M. 1921. Précis de la parasitologie humaine, 5 th ed. J. Lemaire, Paris.

14. Owen, R. J., L. R. Hill, and S. P. Lapage. 1969. Determination of DNA base compositions from melting profiles in dilute buffers. Biopolymers 7:503-516.

15. Paterson, W. D., D. Douey, and D. Desautels. 1980. Relationship between selected strains of typical and atypical Aeromonas salmonicida, Aeromonas hydrophila, and Haemophilus piscium. Can. J. Microbiol. 26:588-598.

16. Pohl, S. 1981. DNA relatedness among members of Haemophilus, Pasteurella, and Actinobacillus, p. 245-253. In M. Kilian, W. Frederiksen, and E. L. Biberstein (ed.), Haemophilus, Pasteurella, and Actinobacillus. Academic Press, Inc., London.

17. Pohl, S., H. U. Bertschinger, W. Frederiksen, and W. Mannheim. 1983. Transfer of Haemophilus pleuropneumoniae and the Pasteurella haemolytica-like organism causing porcine necrotic pleuropneumonia to the genus Actinobacillus (Actinobacillus pleuropneumoniae comb. nov.) on the basis of phenotypic and deoxyribonucleic acid relatedness. Int. J. Syst. Bacteriol. 33:510-514.

18. Ursing, J. 1981. Deoxyribonucleic acid hybridization studies of gas producing Pasteurellae, p. 255-263. In H. Kilian, W. Frederiksen, and E. L. Biberstein (ed.), Haemophilus, Pasteurella, and Actinobacillus. Academic Press, Inc., London. 